\title{
Observations male flight of the cherry bark tortrix (Enarmonia formosana Scop.) in an apple orchard during 2016-2020
}

\author{
Obserwacje lotu samców zwójki koróweczki (Enarmonia \\ formosana Scop.) w sadzie jabłoniowym w latach 2016-2020
}

\author{
Krzysztof Gasparski ${ }^{1 *}$, Barbara Łabanowska², Gabriel Łabanowski ${ }^{2}$
}

\section{Summary}

The cherry bark tortrix (Enarmonia formosana Scop.) is an important pest of fruit plants in many regions of Poland and its role is increasing. This was confirmed by a survey conducted among fruit growers, over $40 \%$ of them considered it a dangerous pest of orchards. Monitoring of the cherry bark tortrix by catching males into pheromone traps allows to determine the time of moths' flight and designate the optimal dates of control. Control is necessary during the period of intense moths flight, because only by destroying the moths it is possible to reduce egg laying and caterpillar feeding. Chemical treatments against codling moth and leaf rollers are not fully effective in reducing the cherry bark tortrix.

Key words: cherry bark tortrix, monitoring, pheromone traps, apple orchard

\section{Streszczenie}

Zwójka koróweczka (Enarmonia formosana Scop.) jest ważnym szkodnikiem roślin sadowniczych w wielu rejonach Polski i jej rola wzrasta. Potwierdziły to badania ankietowe przeprowadzone wśród sadowników, z których ponad 40\% uznało ją za groźnego szkodnika sadów. Monitoring zwójki koróweczki metodą odławiania samców w pułapki feromonowe pozwala określić przebieg lotu motyli i wyznaczyć optymalne terminy zwalczania. Zwalczanie konieczne jest w okresie intensywnego lotu motyli, gdyż tylko niszcząc motyle można ograniczyć składanie jaj i żerowanie gąsienic. Zabiegi chemiczne zwalczające owocówkę jabłkóweczkę i zwójki liściowe, nie są w pełni skuteczne w ograniczeniu zwójki koróweczki.

Słowa kluczowe: zwójka koróweczka, monitoring, pułapki feromonowe, sad jabłoniowy

Pęchów 12a, 27-640 Klimontów

2Północna 64, 96-100 Skierniewice

*corresponding author: boncza.gasparski@gmail.com 


\section{Wstęp / Introduction}

Zwójka koróweczka (Enarmonia formosana Scop.) jest motylem z rodziny zwójkowatych (Tortricidae), do której zaliczanych jest kilka groźnych szkodników roślin sadowniczych. Gąsienice większości z nich żerują na liściach i owocach drzew i krzewów owocowych oraz roślin ozdobnych i dzikorosnących. Gąsienice zwójki koróweczki żerują pod korą drzew owocowych, w tym jabłoni, gruszy, moreli, brzoskwini, śliwy, wiśni, ale też cydonii, jarzębiny, głogu i buku zwyczajnego (Tanigoshi i Stary 2003). Najmłodsze larwy zwójki koróweczki żerują pod korą, w zewnętrznej części łyka, natomiast starsze stadia larwalne zasiedlają i uszkadzają przestrzeń między korą a kambium, w wyniku czego następuje pękanie kory (Jenner i wsp. 2004). Oprócz szkód bezpośrednich, zwójka koróweczka jest przyczyną szkód pośrednich, gdyż uszkodzone miejsca mogą być zasiedlane przez szkodniki wtórne np. chrząszcze, ale też grzyby patogeniczne, a ponadto drzewa są bardziej wrażliwe na niekorzystne warunki pogodowe (Dickler i Zimmermann 1972). Zwójka koróweczka rozpowszechniona jest w zachodniej Europie, Afryce Północnej, Azji Mniejszej oraz w Rosji aż po Syberię (Toshova i wsp. 2017). Na kontynencie amerykańskim, notowana była po raz pierwszy w zachodniej części Kanady, w rejonie British Columbia w 1989 roku (Dang i Parker 1990) i stopniowo przemieszczała się do zachodnich stanów USA. Według Breedveld i Tanigoshi (2007) lot motyli zwójki koróweczki w stanie Washington trwał od maja do września, a najliczniej motyle odławiano w lipcu i sierpniu. W Polsce zwójka koróweczka jest od dawna znanym szkodnikiem (Koślińska i wsp. 1977/78a, b; Koślińska 1978; Płuciennik i wsp. 1996). W latach siedemdziesiątych i osiemdziesiątych dwudziestego wieku niszczyła drzewa w sadach morelowych w rejonie sandomierskim, w którym wówczas warunki klimatyczne najbardziej sprzyjały uprawie moreli w Polsce. Notowana była także na czereśniach. Generalnie w tamtym okresie zwójka była obserwowana głównie w starszych sadach, gdzie kora na pniach była już stosunkowo gruba i często spękana. Przez ostatnie 20 lub więcej lat, zwójka koróweczka zaaklimatyzowała się także w innych rejonach sadowniczych, a ponadto uszkadza również coraz młodsze drzewa. $Z$ obserwacji własnych, a także innych doradców i sadowników prowadzących regularne monitoringi w sadach wynika, iż obecnie największe szkody zwójka koróweczka wyrządza w sadach jabłoniowych. Liczne występowania tego szkodnika we wschodniej części Polski potwierdzone zostało także w publikacjach (Wilk i wsp. 2015).

Zwalczanie zwójki koróweczki w Polsce jest konieczne w wielu sadach. Prace nad jej zwalczaniem prowadziła Koślińska i wsp. (1977/78a, b). Dostępne wówczas środki fosforoorganiczne i inne, stosowano do opryskiwania pni i konarów w okresie lotu motyli i żerowania gąsienic. Dynamikę lotu określano na podstawie liczby wylinek znaj- dowanych na pniach, po wylocie motyli (Koślińska 1978). Zdecydowanie łatwiej i bardziej precyzyjnie okres lotu motyli można było określić po ukazaniu się atraktantów płciowych samicy, umieszczanych w pułapkach służących do wabienia i odłowu samców zwójki koróweczki (Płuciennik i wsp. 1996).

Celem pracy było prześledzenie lotu samców zwójki koróweczki na podstawie ich odłowu w pułapki typu Delta wyposażone w atraktant płciowy samicy i próba oceny wpływu temperatury powietrza na przebieg lotu.

\section{Materiały i metody / Materials and methods}

Obserwacje lotu zwójki koróweczki prowadzono przez 5 lat, w latach 2016-2020, w sadzie produkcyjnym w miejscowości Dziuchów, w gminie Niemce, w powiecie lubelskim. Motyle odławiano w pułapki typu Delta z atraktantem płciowym samicy, wyprodukowanym przez Chemipan, Zakład Doświadczalny Instytutu Chemii Fizycznej Polskiej Akademii Nauk w Warszawie. Na kwaterze o powierzchni 1 ha jabłoni odmiany Golden Delicious zawieszano 1 pułapkę, w której dwukrotnie w sezonie wymieniano feromon. Drzewka na podkładce M 26 posadzono w formie szpaleru w rozstawie $4 \times 2 \mathrm{~m}$, na glebie klasy bonitacyjnej III. $\mathrm{W}$ okresie prowadzenia badań zbierano około 40 ton owoców z ha. W sadzie prowadzono standardową ochronę przed szkodnikami, stosując zwykle preparat fosforoorganiczny np. Reldan 225 EC przed kwitnieniem do zniszczenia głównie gąsienic zwójkówek i innych szkodników, a po kwitnieniu preparaty z grupy neonikotynoidów np. Mospilan 20 SP lub Calypso 480 EC, którymi zwalczano owocnicę i mszyce. W okresie lotu motyli owocówki i zwójek liściowych w późniejszym terminie porównywano liczbę odłowionych motyli z progiem zagrożenia i stosowano Coragen 200 SC oraz Steward $30 \mathrm{WG}$.

Pułapki sprawdzano co 2-5 dni, notowano liczbę odłowionych motyli zwójki koróweczki i następnie usuwano je z podłogi lepowej, co ułatwiało dalsze obserwacje. Średnią temperaturę powietrza i sumę temperatur efektywnych, dla lat 2016-2020, liczoną od 1 marca, przyjmując dolny próg termiczny $10^{\circ} \mathrm{C}$, podano w tabeli 1 . Uzyskane wyniki jako dynamikę odłowu samców przedstawiono w tabeli 2 i 3, zaś przebieg lotu motyli na tle średniej temperatury dobowej przedstawiono na rysunkach $1-5$.

\section{Wyniki i dyskusja / Results and discussion}

Średnie temperatury miesięczne i suma temperatur efektywnych od marca do sierpnia wskazują, że okresy wegetacji w latach 2018 i 2019 były cieplejsze od pozostałych lat prowadzenia obserwacji (tab. 1). Z sumarycznych danych wynika, że lot motyli zwójki koróweczki w sadzie we 


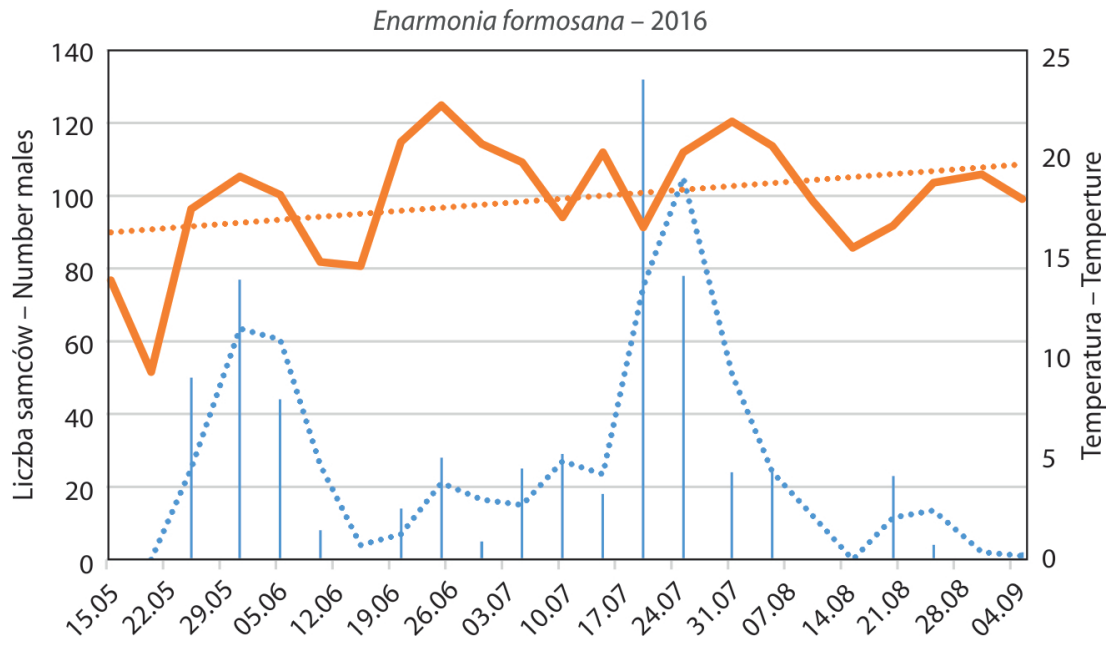

Rys. 1. Dynamika odłowu samców zwójki koróweczki w 2016 r.

Fig. 1. The catch dynamics of the cherry bark tortrix males in 2016

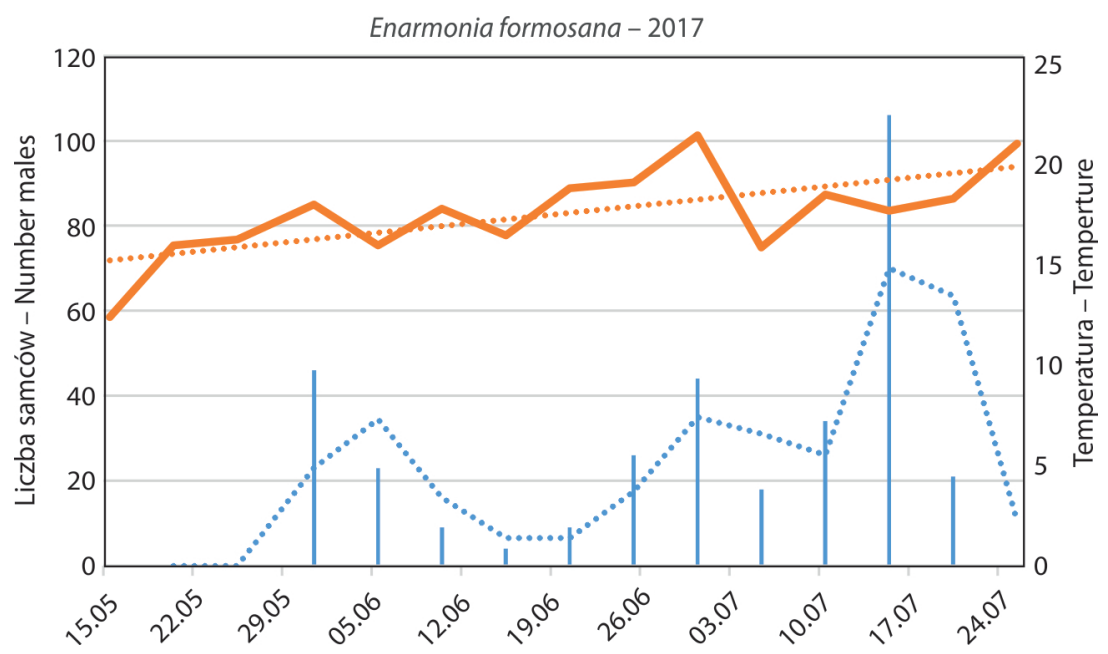

Rys. 2. Dynamika odłowu samców zwójki koróweczki w 2017 r.

Fig. 2. The catch dynamics of the cherry bark tortrix males in 2017

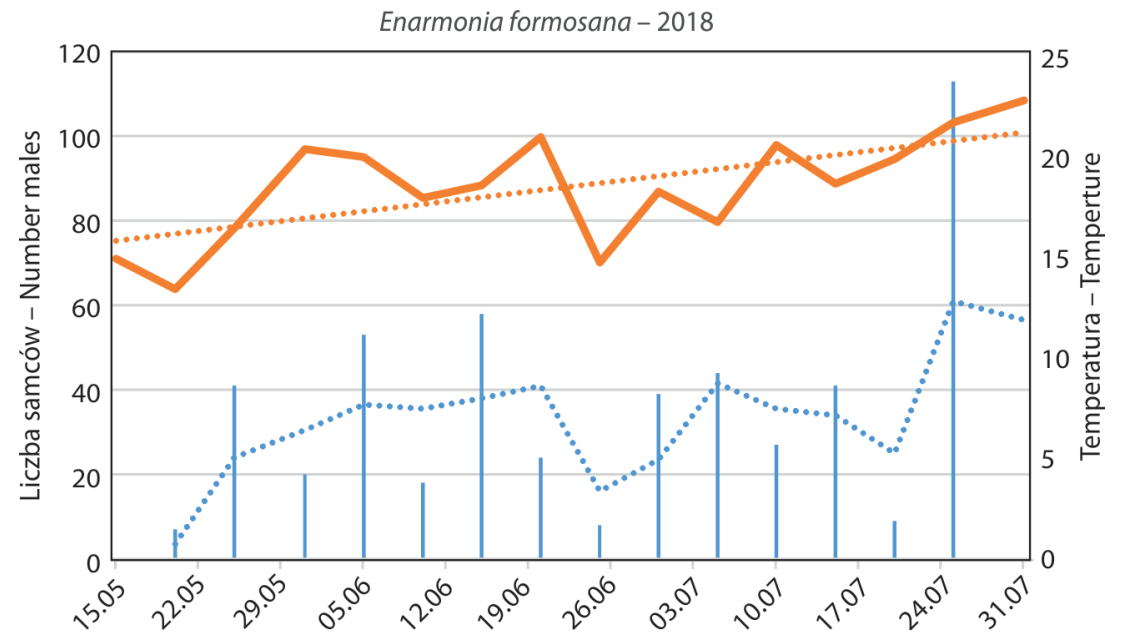

Rys. 3. Dynamika odłowu samców zwójki koróweczki w 2018 r.

Fig. 3. The catch dynamics of the cherry bark tortrix males in 2018 


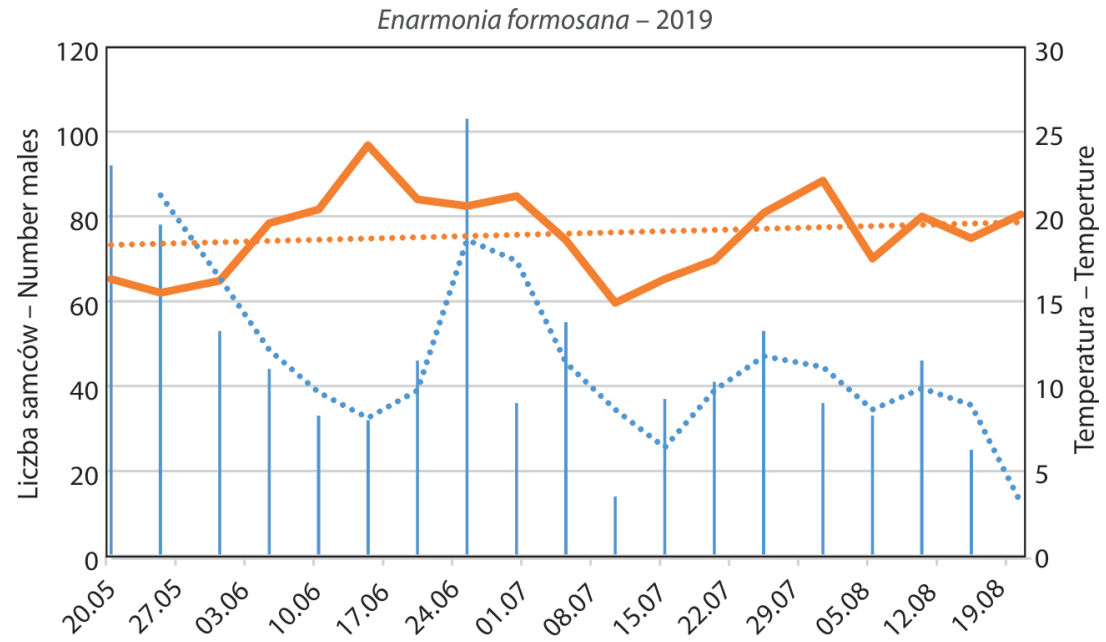

Rys. 4. Dynamika odłowu samców zwójki koróweczki w 2019 r.

Fig. 4. The catch dynamics of the cherry bark tortrix males in 2019

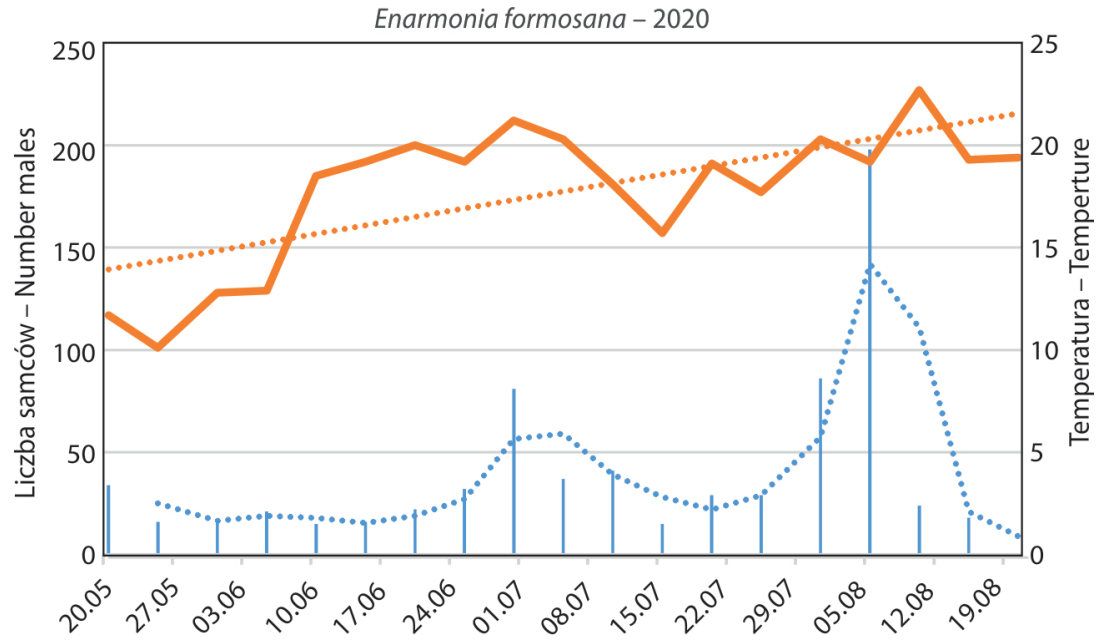

Rys. 5. Dynamika odłowu samców zwójki koróweczki w 2020 r.

Fig. 5. The catch dynamics of the cherry bark tortrix males in 2020

wschodnim rejonie kraju rozpoczynał się od około połowy do końca maja i kończył w okresie od drugiej połowy lipca do połowy sierpnia, a więc trwał 52 do 105 dni, średnio dla lat 78 dni (tab. 2). Przebieg temperatury wiosną w niektóre lata, np. w roku 2020, mógł mieć wpływ na termin wylotu, ale nie zawsze było to zauważalne. Zwykle notowano dwa wzmożone okresy lotu motyli, pierwszy w maju lub w pierwszej połowie czerwca, a drugi od połowy do końca lipca, początku sierpnia, zależnie od sezonu.

Analiza danych przedstawionych w tabeli 3. wskazuje, że w czerwcu i lipcu w latach 2016-2018 odłowiono około lub ponad $70 \%$ całej populacji motyli, zaś w latach 2019-2020 około 60\%, przy czym w poszczególnych latach rozkład odłowionych motyli był różny i zależał w znacznym stopniu od temperatury powietrza.
W 2016 roku motyle odławiały się od początku trzeciej dekady maja do początku września (rys. 1, tab. 2). Do 25 maja odłowiono 50 motyli i następnie wyższy pik obserwowano pod koniec maja, natomiast dość wysokie odłowy, ponad 75 motyli w pułapce, stwierdzono 3 czerwca. Po tym okresie notowano zdecydowanie mniejsze wyloty, ale na przełomie drugiej i trzeciej dekady lipca nastąpiły masowe wyloty i maksymalne odłowy, kiedy to w ciągu okresu 5 dni odławiało się nawet 132 motyli. Po tym czasie liczba motyli w pułapce, w kolejnych dniach obserwacji, obniżyła się do poziomu około 20 osobników. Generalnie lot motyli był bardzo rozciągnięty w czasie, trwał ponad 3 miesiące, podczas których notowano dwa wyraźnie wzmożone okresy lotu, na co wskazały najwyższe liczby samców w pułapkach. Liczba odłowionych 
Tabela 1. Średnia temperatura miesięczna i suma temperatur efektywnych, Dziuchów 2016-2020

Table 1. Average monthly temperature and the sum of effective temperatures, Dziuchów 2016-2020

\begin{tabular}{|c|c|c|c|c|c|}
\hline \multirow{2}{*}{$\begin{array}{l}\text { Miesiąc } \\
\text { Month }\end{array}$} & 2016 & 2017 & 2018 & 2019 & 2020 \\
\hline & \multicolumn{5}{|c|}{ średnia temperatura miesięczna - average monthly temperature $\left[{ }^{\circ} \mathrm{C}\right]$} \\
\hline III & $3,9^{*}$ & 5,7 & $-0,6$ & 5,0 & 4,2 \\
\hline IV & 9,1 & 7,4 & 13,2 & 9,4 & 8,5 \\
\hline $\mathrm{V}$ & 14,4 & 13,8 & 16,5 & 13,0 & 11,3 \\
\hline VI & 18,3 & 18,0 & 18,2 & 21,2 & 18,5 \\
\hline VII & 19,1 & 18,3 & 20,0 & 18,4 & 18,6 \\
\hline VIII & 17,9 & 19,1 & 20,0 & 19,6 & 15,2 \\
\hline Średnia - Average & 14,7 & 13,7 & 14,5 & 14,4 & 12,7 \\
\hline Miesiąc - Month & \multicolumn{5}{|c|}{ suma temperatur efektywnych - sum of effective temperatures } \\
\hline III & 0,0 & 4,1 & 0,0 & 0,6 & 1,0 \\
\hline IV & 21,8 & 20,6 & 115,1 & 37,9 & 23,8 \\
\hline $\mathrm{V}$ & 144,2 & 134,8 & 202,4 & 106,7 & 56,3 \\
\hline VI & 250,3 & 239,1 & 247,0 & 334,6 & 254,9 \\
\hline VII & 282,1 & 257,8 & 309,4 & 259,2 & 265,8 \\
\hline VIII & 243,8 & 282,1 & 310,0 & 296,3 & 300,8 \\
\hline Suma - Totals & 942,2 & 938,5 & 1183,9 & 1035,3 & 902,64 \\
\hline
\end{tabular}

*od 16-31 marca - for March 16-31

Tabela 2. Dynamika lotu samców zwójki koróweczki w latach 2016-2020 w Dziuchowie Table 2. The flight dynamics of cherry bark tortrix males during 2016-2020 in Dziuchów

\begin{tabular}{|c|c|c|c|c|c|c|c|c|c|c|c|}
\hline \multirow{3}{*}{$\begin{array}{c}\text { Rok ob- } \\
\text { serwacji } \\
\text { Year of } \\
\text { observa- } \\
\text { tion }\end{array}$} & \multirow{3}{*}{$\begin{array}{c}\text { Liczba } \\
\text { samców } \\
\text { w sezo- } \\
\text { nie } \\
\text { Number } \\
\text { males } \\
\text { in season }\end{array}$} & \multicolumn{10}{|c|}{ Suma temperatur efektywnych do pojawu - Sum of effective temperature till the moment of emergence of } \\
\hline & & \multicolumn{2}{|c|}{$\begin{array}{l}\text { pierwszego motyla } \\
\text { the first moth }\end{array}$} & \multicolumn{2}{|c|}{$\begin{array}{c}10 \% \text { motyli } \\
10 \% \text { of moths }\end{array}$} & \multicolumn{2}{|c|}{$\begin{array}{c}50 \% \text { motyli } \\
50 \% \text { of moths }\end{array}$} & \multicolumn{2}{|c|}{$\begin{array}{l}90 \% \text { motyli } \\
90 \% \text { of moths }\end{array}$} & \multicolumn{2}{|c|}{$\begin{array}{l}\text { ostatniego motyla } \\
\text { the last moth }\end{array}$} \\
\hline & & $\begin{array}{l}\text { data } \\
\text { date }\end{array}$ & $\begin{array}{c}\text { suma } \\
\text { temperatur } \\
\text { efektywnych } \\
\text { sum } \\
\text { of effective } \\
\text { temperature }\end{array}$ & $\begin{array}{l}\text { data } \\
\text { date }\end{array}$ & $\begin{array}{c}\text { suma } \\
\text { temperatur } \\
\text { efetywnych } \\
\text { sum } \\
\text { of effective } \\
\text { temperature }\end{array}$ & $\begin{array}{l}\text { data } \\
\text { date }\end{array}$ & $\begin{array}{c}\text { suma } \\
\text { temperatur } \\
\text { efektywnych } \\
\text { sum } \\
\text { of effective } \\
\text { temperature }\end{array}$ & $\begin{array}{l}\text { data } \\
\text { date }\end{array}$ & $\begin{array}{c}\text { suma } \\
\text { temperatur } \\
\text { efektywnych } \\
\text { sum } \\
\text { of effective } \\
\text { temperature }\end{array}$ & $\begin{array}{l}\text { data } \\
\text { date }\end{array}$ & $\begin{array}{c}\text { suma } \\
\text { temperatur } \\
\text { efektywnych } \\
\text { sum } \\
\text { of effective } \\
\text { temperature }\end{array}$ \\
\hline 2016 & 585 & 23.05 & 98,2 & 26.05 & 118,8 & 13.07 & 381,6 & 27.07 & 458,3 & 5.09 & 980,6 \\
\hline 2017 & 340 & 27.05 & 120,8 & 28.05 & 128,6 & 1.07 & 405,0 & 14.07 & 497,9 & 18.07 & 545,1 \\
\hline 2018 & 502 & 17.05 & 214,3 & 26.05 & 266,7 & 28.06 & 528,9 & 21.07 & 752,1 & 21.07 & 798,4 \\
\hline 2019 & 857 & 16.05 & 52,3 & 19.05 & 72 & 22.06 & 390 & 3.08 & 76 & 14.08 & 870,1 \\
\hline 2020 & 731 & 17.05 & 53,0 & 5.06 & 95,5 & 28.07 & 575,6 & 16.08 & 769,6 & 3.08 & 628,9 \\
\hline $\begin{array}{l}\text { Średnia } \\
\text { Average }\end{array}$ & 603 & $\begin{array}{l}16.05 \\
27.05\end{array}$ & 107,7 & $\begin{array}{c}19.05- \\
05.06\end{array}$ & 136,4 & $\begin{array}{l}22.06- \\
28.07\end{array}$ & 456,2 & $\begin{array}{c}14.07- \\
16.08\end{array}$ & 648,0 & $\begin{array}{c}18.07- \\
14.08\end{array}$ & 764,6 \\
\hline
\end{tabular}

Tabela 3. Liczba odłowionych motyli zwójki koróweczki i średnia miesięczna temperatura powietrza, Dziuchów 2016-2020 Table 3. The number of caught the cherry bark tortrix males and the monthly air temperature, Dziuchów 2016-2020

\begin{tabular}{|c|c|c|c|c|c|c|c|c|c|}
\hline \multirow[b]{2}{*}{$\begin{array}{c}\text { Rok obserwacji } \\
\text { Year of } \\
\text { observation }\end{array}$} & \multirow[b]{2}{*}{$\begin{array}{c}\text { Liczba } \\
\text { motyli } \\
\text { w sezonie } \\
\text { Number } \\
\text { of moths } \\
\text { in season }\end{array}$} & \multicolumn{2}{|c|}{ Maj-May } & \multicolumn{2}{|c|}{ Czerwiec - June } & \multicolumn{2}{|c|}{ Lipiec - July } & \multicolumn{2}{|c|}{ Sierpień - August } \\
\hline & & $\begin{array}{c}\text { liczba } \\
\text { motyli } \\
\text { [w \%] } \\
\text { number } \\
\text { of moths } \\
\text { [in \%] }\end{array}$ & $\begin{array}{c}\text { temperatura } \\
\text { temperature } \\
{\left[{ }^{\circ} \mathrm{C}\right]}\end{array}$ & $\begin{array}{c}\text { liczba } \\
\text { motyli } \\
\text { [w \%] } \\
\text { number } \\
\text { of moths } \\
{[\text { in } \%]}\end{array}$ & $\begin{array}{c}\text { temperatura } \\
\text { temperature } \\
{\left[{ }^{\circ} \mathrm{C}\right]}\end{array}$ & $\begin{array}{c}\text { liczba } \\
\text { motyli } \\
\text { [w \%] } \\
\text { number } \\
\text { of moths } \\
{[\text { in } \%]}\end{array}$ & $\begin{array}{c}\text { temperatura } \\
\text { temperature } \\
{\left[{ }^{\circ} \mathrm{C}\right]}\end{array}$ & $\begin{array}{c}\text { liczba } \\
\text { motyli } \\
\text { [w \%] } \\
\text { number } \\
\text { of moths } \\
\text { [in \%] }\end{array}$ & $\begin{array}{c}\text { temperatura } \\
\text { temperature } \\
{\left[{ }^{\circ} \mathrm{C}\right]}\end{array}$ \\
\hline 2016 & 585 & 21,7 & 14,4 & 16,9 & 18,3 & 52,3 & 19,1 & 9,1 & 17,9 \\
\hline 2017 & 340 & 13,5 & 13,8 & 33,9 & 18,0 & 52,6 & 18,3 & 0,0 & 19,1 \\
\hline 2018 & 502 & 13,5 & 16,5 & 39,9 & 18,2 & 46,6 & 20,0 & 0,0 & 20,0 \\
\hline 2019 & 857 & 26,0 & 13,0 & 34,3 & 21,2 & 27,6 & 18,4 & 12,1 & 19,6 \\
\hline 2020 & 731 & 9,2 & 11,3 & 25,6 & 18,5 & 32,4 & 18,6 & 32,8 & 19,8 \\
\hline $\begin{array}{l}\text { Średnie } \\
\text { Average }\end{array}$ & 603 & 16,8 & 13,8 & 30,1 & 18,8 & 42,3 & 18,9 & 10,8 & 19,3 \\
\hline
\end{tabular}


samców była dość wysoka, wynosiła blisko 600 osobników w sezonie.

W 2017 roku pierwsze motyle notowano na początku trzeciej dekady maja, a już do 31 maja odłowiono 46 motyli w pułapkę (rys. 2, tab. 2). W czerwcu odławiało się znacznie mniej motyli, ale pod koniec miesiąca notowano wzmożony lot, gdyż pierwszego lipca w pułapce było blisko 50 motyli. Najbardziej intensywny lot miał miejsce w drugiej dekadzie lipca, kiedy to do 15 lipca odłowiono maksymalną liczbę, około 106 motyli w ciągu 5 dni. Sumarycznie w 2017 roku odłowiono znacznie mniej motyli niż w pierwszym roku obserwacji.

W 2018 roku pierwsze motyle odłowiono w połowie maja, ale bardziej intensywny lot obserwowano w pierwszej połowie czerwca i pierwszej połowie lipca, kiedy w okresie najbardziej intensywnego lotu w pułapkach znajdowano ponad 40, a nawet blisko 60 motyli odłowionych w ciągu 5 dni (rys. 3, tab. 2). Najwięcej samców w pułapkę odłowiło się na przełomie drugiej i trzeciej dekady lipca, kiedy to 22 lipca w pułapce stwierdzono ponad 100 motyli. W ciągu całego okresu prowadzenia monitoringu odłowiono ponad 500 motyli.

W 2019 roku intensywny lot motyli rozpoczął się już w maju, kiedy to w ostatniej dekadzie odławiano 70-90 samców w ciągu 5 dni (rys. 4, tab. 2). W kolejnych terminach obserwacji znajdowano od 30 do 40 motyli w pułapce, a najbardziej intensywny lot obserwowano w trzeciej dekadzie czerwca, kiedy odłowiło się ponad 100 samców w ciągu kolejnego okresu obserwacji. Po tym terminie intensywność lotu motyli zmniejszyła się, chociaż motyle odławiały się do połowy sierpnia, a ich liczba w prawie wszystkich terminach obserwacji była na poziomie około 40 osobników, z wyjątkiem ostatniej obserwacji, ponad 20 osobników. Generalnie w całym sezonie liczba odłowionych samców była dość wysoka, ponad 850 osobników.

W 2020 roku lot motyli rozpoczął się w połowie maja, ale przez 5-6 tygodni odławiało się tylko po 15-20 motyli w okresie 5 dni (rys. 5, tab. 2). Najbardziej intensywny lot motyli, a tym samym odłowy samców na poziomie około 80 osobników w ciągu 5 dni notowano na przełomie czerwca i lipca oraz na przełomie lipca i sierpnia. W lipcu odłowy były nieco wyższe niż w czerwcu, nawet 30-40 motyli pomiędzy okresami obserwacji. Bardziej intensywny lot miał miejsce przez pierwsze 2 dekady sierpnia, po około 50 motyli w ciągu 5 dni. W sezonie od maja do końca sierpnia odłowiono ponad 600 samców zwójki koróweczki.

Podsumowując, obserwowany przebieg lotu motyli wskazuje na występowanie jednego pokolenia, ale jest on rozciągnięty w czasie i występują zwykle dwa liczniejsze szczyty lotu. Wyniki obserwacji własnych są zbieżne z wcześniejszymi danymi uzyskanymi w innych rejonach Polski (Koślińska 1978; Płuciennik i wsp. 1996), a także z danymi zamieszczonymi w literaturze, w Bułgarii (Toshova i wsp. 2017), czy też na Ukrainie (Chayka i wsp. 2014). Pewne różnice w okresie występowania szczytów lotu mogą wynikać z przebiegu temperatury powietrza oraz zabiegów chemicznych zwalczających owocówkę jabłkóweczkę i zwójkówki liściowe.

Należy podkreślić, że zwójka koróweczka jest ważnym szkodnikiem roślin sadowniczych i jej rola wzrasta, na co wskazują wyniki ankiety autora przeprowadzonej wśród 134 sadowników w 2020 roku. Spośród nich, 40\% uznaje zwójkę koróweczkę za groźnego szkodnika, a prawie 17\% nie wie, jaki jest poziom jej szkodliwości. Wśród ankietowanych ponad 83\% sadowników korzysta z komunikatów doradców, ale monitoring lotów tego szkodnika za pomocą pułapek feromonowych prowadzi tylko niespełna $23 \%$ sadowników. Około 40\% ankietowanych zauważyło, że część drzew jest osłabionych, a u nielicznych producentów nawet usycha. Największe szkody, ponad 48\% według ankietowanych szkodnik ten wyrządza na odmianie Szampion i jego sportach Szampion Reno i Szampion Arno. Dodatkowo po około 20\% ankietowanych wskazało, że największe szkody powodowane przez zwójkę koróweczkę obserwują na odmianach: Gala, Jonagoldy oraz Elise. Mimo, iż obecnie nie ma zarejestrowanych insektycydów do zwalczania zwójki koróweczki w Polsce, to 36\% ankietowanych sadowników deklaruje, że wykonując 1-2 zabiegi zwalczające owocówkę jabłkóweczkę i inne zwójki, pośrednio zwalcza także E. formosana. Kolejne 31\% ankietowanych sadowników wskazało na uboczne zwalczanie zwójki koróweczki wykonując rocznie 2-4 zabiegi środkami owadobójczymi. Prawie $10 \%$ ankietowanych sadowników uważa za konieczne wykonanie minimum pięciu zabiegów i więcej w sezonie w celu ograniczania tego szkodnika.

Przebieg lotu tego szkodnika w kraju zależy od rejonów i dlatego bardzo ważne jest, aby obserwować lot motyli w każdym rejonie sadowniczym, na najważniejszych gatunkach drzew (Koślińska 1978; Płuciennik i wsp. 1996). Mimo, że monitoring lotu prowadzono w sadach chronionych przed owocówką jabłkóweczką i zwójkami liściowymi, odławiano duże liczby motyli zwójki koróweczki. Wyniki te wskazują na konieczność prowadzenia dodatkowych zabiegów w okresie masowego lotu motyli zwójki koróweczki, a w wyznaczeniu optymalnych terminów najważniejszą rolę odgrywają obserwacje lotu motyli odławianych w pułapki feromonowe. Uzyskane wyniki są zgodne z danymi publikowanymi wcześniej w Polsce i innych krajach.

\section{Wnioski / Conclusions}

1. Monitoring lotu motyli zwójki koróweczki w sadzie we wschodnich rejonach Polski, na podstawie odławiania samców w pułapki feromonowe wskazuje, że jest to ważny szkodnik sadów jabłoniowych tego regionu.

2. Monitoring jest konieczny w każdym rejonie sadowniczym, a nawet w każdym sadzie, gdyż pozwala określić przebieg lotu motyli i wskazać optymalne terminy zwalczania szkodnika. 
3. Monitoring lotu motyli zwójki koróweczki prowadzony w sadach chronionych wskazuje, że zabiegi chemiczne zwalczające owocówkę jabłkóweczkę i zwójki liściowe, nie są w pełni skuteczne w ograniczeniu zwójki koróweczki.

4. W celu redukcji maksymalnej liczby motyli zwójki koróweczki, konieczne jest wprowadzenie zabiegów w okresie intensywnego lotu jej motyli, wyznaczonego poprzez odławianie samców w pułapki feromonowe.

\section{Podziękowanie / Acknowledgements}

Autorzy składają serdeczne podziękowania Panu Łukaszowi Szewczykowi oraz firmie PROCAM za wieloletnią pomoc w monitorowaniu szkodników w miejscowości Dziuchów.

\section{Literatura / References}

Breedveld K.G.H., Tanigoshi L.K. 2007. Seasonal phenology of Enarmonia formosana (Lepidoptera: Tortricidae) and egg parasitism by Trichogramma cacoeciae (Hymenoptera: Trichogrammatidae) in Washington State, USA. Journal Pest Science 80: 15-19. DOI: 10.1007/s10340-006-0144-7

Chayka V.M., Rubezhniak I.G., Petryk O.I. 2014. Phenology of a leafroller complex in apple orchard of forest steppe of Ukraine. European Scientific Journal December 2014 edition, 10 (35): 326-335.

Dang P.T., Parker D.J. 1990. First records of Enarmonia formosana (Scopoli) in North America (Lepidoptera: Tortricidae). Journal of the Entomological Society of British Columbia 87: 3-6.

Dickler E., Zimmermann H. 1972. Investigations on the biology and population dynamics of the bark Tortricid Enarmonia formosana Scop. (Lepid., Tortr.). Untersuchungen zur Biologie und populations dynamik des Rindenwicklers Enarmonia formosana Scop. (Lepid., Tortr.). Mitteilungen aus der Biologischen Bundesanstalt fur Land- und Forstwirtschaft Berlin-Dahlem 144: 143-150.

Jenner W., Kuhlmann U., Cossentine J., Roitberg B. 2004. Phenology, distribution, and the natural parasitoid community of the cherry bark tortrix. Biological Control 31 (1): 72-82. DOI: 10.1016/j.biocontrol.2004.05.007

Koślińska M. 1978. Dynamika wylotu motyli zwójki koróweczki - Enarmonia formosana Scop. (Lep., Tortricidae) i przeziernika jabłoniowca - Synanthedon myopiformis Borkh. (Lep., Aegeriidae). [The rate of emergence of the bark borer-Enarmonia formosana Scop. (Lep., Tortricidae) and apple clear wing moth - Synanthedon myopiformis Borkh., (Lep., Aegeriidae)]. Polskie Pismo Entomologiczne 48 (1): 129-136.

Koślińska M., Iwanek B., Parynow H., Szczepanik Z. 1977/78a. Zwalczanie zwójki koróweczki (Enarmonia formosana Scop., Lep., Tortricidae) i przeziernika jabłoniowca (Synanthedon myopiformis Borkh., Lep., Aegeridae) w sadach jabłoniowych. Prace Instytutu Sadownictwa, Seria A, 20: 229-240.

Koślińska M., Suski Z.W., Wojnicki S., Karolczak W. 1977/78b. Zwalczanie zwójki koróweczki (Enarmonia formosana Scop., Lep.: Tortricidae) na morelach i czereśniach. Prace Instytutu Sadownictwa, Seria A, 20: 241-248.

Płuciennik Z., Tworkowska U., Banyś M., Brożbar J. 1996. Fenologia lotu zwójki koróweczki - Enarmonia formosana Scop. w Polsce w latach 1987-1994. Zeszyty Naukowe Instytutu Sadownictwa i Kwiaciarstwa 3: 99-114.

Tanigoshi L.K., Stary P. 2003. Distribution, habitats and host plants of the cherry bark tortrix, Enarmonia formosana (Scopoli) in the Czech Republic (Lepidoptera, Tortricidae). Journal of Pest Science 76 (2): 41-43. DOI: 10.1046/j.1439-0280.2003.03011.x

Toshova B., Zlatkov B., Subchev M., Tóth M. 2017. Monitoring the seasonal flight activity of three tortricid pests in Bulgaria with a single sex pheromone-baited trap. Acta Zoologica Bulgarica 69 (2): 283-292.

Wilk E., Wojciechowicz-Żytko E., Olbrycht T., Konieczna K. 2015. Występowanie zwójek (Lepidoptera, Tortricidae) w sadach jabłoniowych z integrowaną produkcją. [Occurrence of Tortricidae (Lepidoptera) in apple orchards with integrated production]. Episteme 26/2015, t. II: $391-398$. 